\title{
9 Indigenous policy and Indigenous data in Mexico
}

\section{Context, challenges and perspectives}

\author{
Oscar Luis Figueroa Rodríguez
}

\section{Introduction: Indigenous population in Mexico}

The Political Constitution of the Mexican United States (Mexico) establishes under the 2nd article that:

The Nation has a multicultural composition originally supported by its Indigenous people, which are those that descend from populations that inhabited the actual territory of the country at the beginning of colonization and that preserve their own social, economic, cultural and political institutions, or part of them.

The consciousness of their Indigenous identity should be fundamental criteria to determine to whom Indigenous people ordinances are applied.

Indigenous communities are those that form a social, economic and cultural unit, established in a territory and that recognize their own authorities in accordance with their uses and costumes.

(Constitución Política de los Estados Unidos

Mexicanos, 2019, p. 2)

This definition of indigeneity has been used as the basic reference in any matter regarding public policies toward Indigenous Peoples in Mexico. It is important to point out that the construction of this definition was made by the Constituent Congress in 1917; this Congress was integrated by 218 Congressmen (all men) of which only eight were Indigenous-3.66\% - (Romero, 1978), which clearly indicates that there was not a sufficient number of Indigenous representatives participating in the construction of this definition, narrowing Indigenous communities' influence on their own definition.

It also - in general - aligns with the official definition of the United Nations (United Nations, 2007), The International Labor Organization (Indigenous and Tribal People Convention, n.d.) and the World Bank (Indigenous Peoples, 2019). Nevertheless, in practice its application (defining the exact number of Indigenous People in Mexico and developing a particular public policy for this population) has been a complicated task that has changed over time; in this sense, the concept of "Indigenous" is historical (Rubio, 2014) and thus has been historically defined 
according to the political and ideological context of Mexico's government at the time.

Since the development of the first national census in Mexico in 1895 until the last census in 2010, 13 censuses have been applied throughout the country. The federal government has attempted to quantify the number of inhabitants characterized as Indigenous in each census. Language has been the common criterion used to determine Indigeneity (population that speaks an Indigenous language) (Table 9.1). In the censuses of 1895 and 1921 the criterion of race was included, with the options of being Indigenous, mixed or White. In both cases the registration was done by asking the population what race they were; this could be considered as self-perception as Indigenous (Pla, 2011). In the 1921 census, almost 30\% of the population considered themselves to be Indigenous (Rubio, 2014), even though only $15 \%$ of the population older than five spoke an Indigenous language. In the context presented at the beginning of the 20th century during which the idea of "modernization" was strongly embraced by Porfirio Diaz's government and the ones that followed, being perceived as an Indigenous country was not ideal; therefore, in the preceding censuses of that century the self-perception criterion was no longer included.

The 1930 census incorporated the concepts of monolingual and bilingual; this was a breakthrough for the federal government ability to quantify the proportions of population that spoke Spanish and any other Indigenous language. In the 1921 census, the option of speaking Spanish and another language (Indigenous or foreign) was acknowledged, since previously the instructions for completing the census form in the 1895 and 1900 censuses established that when a person spoke Spanish and an Indigenous language "preference will be given to record Spanish" as their language (INEGI, 2020). This indicated a preference toward not being Indigenous promoted by the state.

The ideological context during the first half of the 20th century supported by the ideas of scholars such as Manuel Gamio and Antonio Caso (both eminent nonIndigenous scholars in Mexico, the first an anthropologist and archaeologist and the second a philosopher) criticized the state's reliance on only language criteria for quantifying the Indigenous population. Gamio suggested the consideration of "race and culture and not just language" and Caso proposed the definition of Indigenous according to four elements: "physical features, culture, language and the sense of community" (Pla, 2011).

Thus, the 1940-1970 censuses incorporated cultural criteria presented as customs and habits to further identify who were Indigenous among the Mexican population. In the 1940 census a number of cultural differentiation criteria were included in the census: footwear-using regular shoes or huaraches ${ }^{1}$ vs. being barefoot; food habits - eating wheat bread vs. tortilla ${ }^{2}$; clothing — material of the trousers or skirt; and if people slept in bed or cot vs. hammock or the floor in petate. $^{3}$ In the 1950 and 1960 censuses, footwear and food habits were considered and in the 1970 census only footwear was considered. As a result of the inclusion of these cultural elements, the number of inhabitants considered as Indigenous increased considerably (Pla, 2011; Rubio, 2014; Carrasco and Alcázar, 2009). 
Table 9.1 Criteria to define "Indigenous population" in Mexico's census

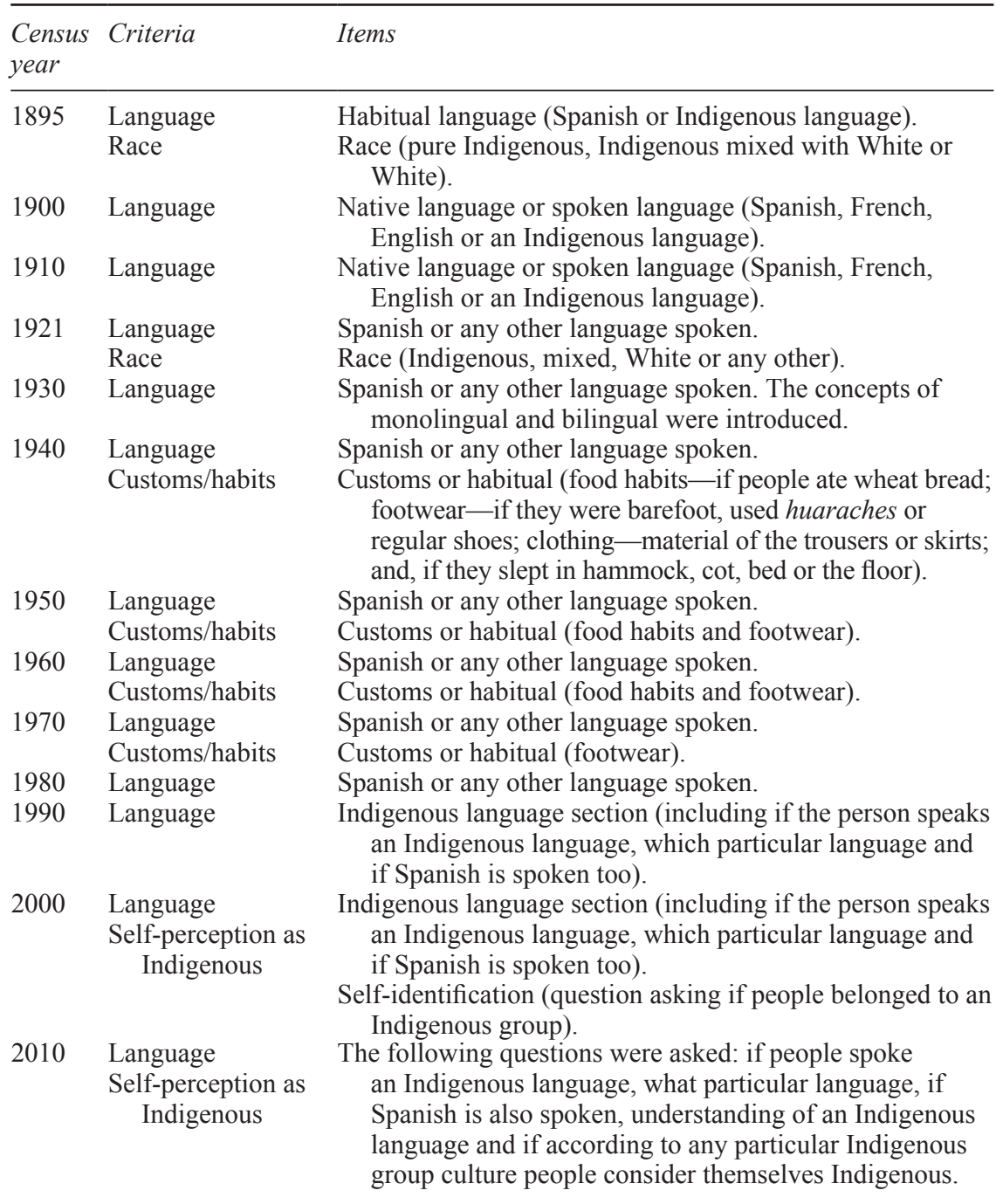

Source: INEGI, Censos y Conteos de Población y Vivienda (https://www.inegi.org.mx/programas/ ccpv/2020/default.html)

Once again this was inconvenient for the state. On one hand, accepting the fact that Mexico was an Indigenous country placed it further away from being a "modern" state. On the other hand, it presented the challenge of establishing a clear frontier between the Indigenous population and that known as "mestizo" which constitutes a continuum (Knight, 2004) since several of the cultural features remained a part of the daily habits of the mestizo population. As a result, Mexico 
dropped the use of cultural criteria in following censuses to avoid further discussions that would lead to topics such as racism.

For the 1980 and 1990 censuses, only language criteria were used. Finally, the last two censuses included the self-perception criteria once again but presented in a different format. In 2000, a question asking if people belonged to an Indigenous group was included. In 2010, a whole section asked questions regarding if people spoke an Indigenous language, if they understood an Indigenous language even though they could not speak it, and if according to any particular Indigenous group culture they considered themselves as part of that culture. For the 2020 census, this section is expected to remain with the inclusion of an option for Afro-descendants too.

\section{Indigeneity definition for public policy: INEGI, CONAPO and INPI}

The institution in charge of the design, application, systematization and presentation of data obtained from the censuses is the National Institute of Geography, Statistics and Informatics (INEGI). ${ }^{5}$ With the data obtained from INEGI, several other agencies develop analyzes and projections about social and economic variables - among others - for the population in general and by interest groups. It is important to mention that in the design and conduction of polls and censuses Indigenous participation has been limited if not null, particularly in the design, in terms of the approaches and interests on the data to be collected and its use.

According to the 2010 census (INEGI, 2010) of 112,336,538 inhabitants in the country, $6.5 \%$ over three years old spoke an Indigenous language and $21.5 \%$ considered themselves to be Indigenous (self-perception). Importantly, in the previous censuses, the age for considering if an individual spoke an Indigenous language was five; for the 2010 census that age was reduced to three, which is the age taken into account ever since. INEGI also performs a number of polls in relation to several topics, including a National Demographic Dynamic Poll (ENADID) ${ }^{6}$ which was last conducted in 2018. This poll was based on projections developed from data gathered from a sample in order to observe trends. The ENADID included an "ethnicity index" composed of the variables (a) population over three years old that speak an Indigenous language and (b) population over three years old that consider themselves to be Indigenous (Figure 9.1). Out of a total population over three years old in Mexico of 119,713,142 inhabitants, 5.9\% speak an Indigenous language; nevertheless, 33.7\% consider themselves to be Indigenous regardless of not speaking an Indigenous language but considering a number of cultural elements commonly related to Indigenous communities and Indigenous lifestyle that people relate with (ENADID, 2018), including being part of an Indigenous household.

These results are interesting and require further analysis in order to better understand why the population that speak Indigenous languages is decreasing (from 6.3 to $5.9 \%$ in the $2006-2018$ period) whilst the population that perceive themselves as Indigenous has increased (from 16.2 to $33.7 \%$ in the same period), taking into account the methodological nuances in both the census and the poll. 


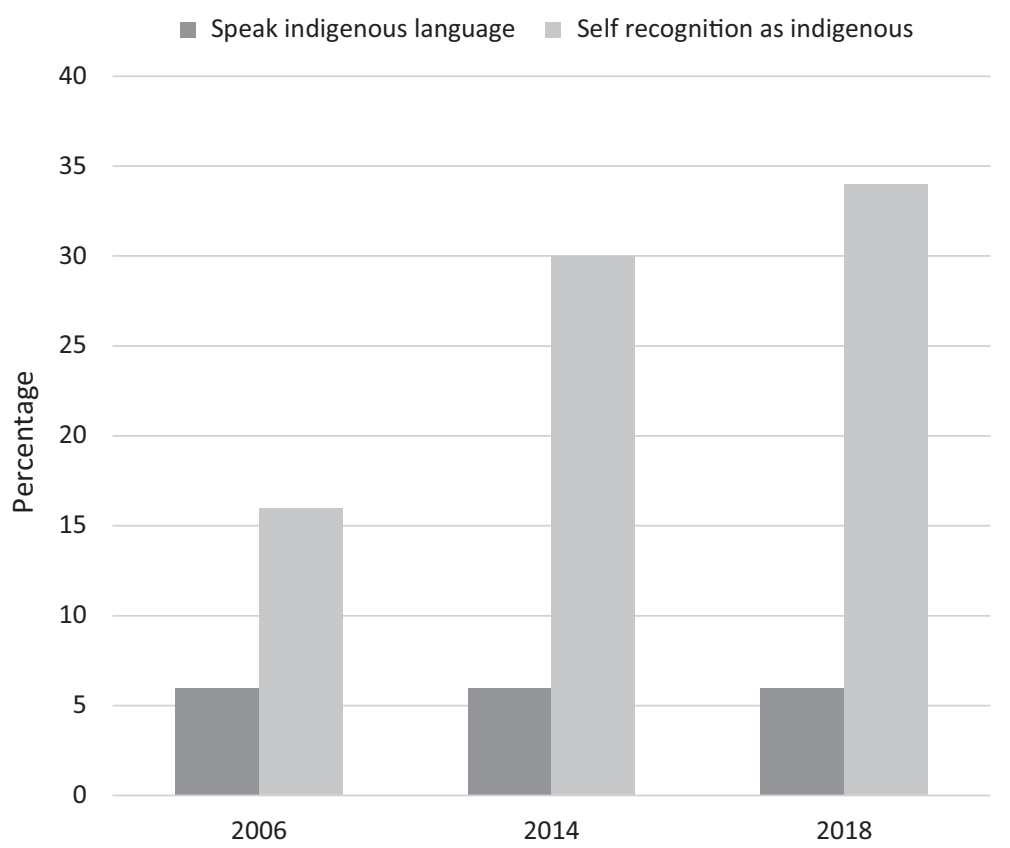

Figure 9.1 Ethnicity index in Mexico (ENADID 2006, 2014, 2018).

The National Population Council (CONAPO) is the organization in charge of demographic planning for the country in order to assure the equal participation of the Mexican population in programs for social and economic development (CONAPO, 2020). CONAPO estimates the Indigenous population in Mexico considering the following criteria: (a) population that speak an Indigenous language; (b) population that perceives themselves as part of an Indigenous group (self-perception) and (c) population that inhabit within a household with an Indigenous member (Indigenous language speaker or self-perceived as Indigenous) except in cases in which Indigenous individuals form part of the domestic service in the house, mainly in urban settings. CONAPO acknowledges the limitation of only considering language as the main criteria to define indigeneity and argue that:

The figures of Indigenous language speakers represent a minimum dimension of the total number of Indigenous, since the penetration of Spanish in formal education, through bilingual schools, has led to the new generations not speaking the native language of their ancestors. Even after the mother tongue has been lost, many descendants of Indigenous language speakers maintain contact with their original communities and preserve several customs. 
The institution in charge of the matters related to the Indigenous and AfroMexican communities is the National Institute for the Indigenous Communities (INPI) ${ }^{7}$ - formerly the National Commission for the Development of Indigenous Communities (CDI) - the purpose of which is to define, design, norm, establish, execute, coordinate, promote, monitor and evaluate policies, programs, projects, strategies and public actions to guarantee the exercise and implementation of Indigenous and Afro-Mexican communities' rights as well as their sustainable development and the strengthening of their culture and identity (INPI, 2020).

During the last administrations (2000-2018) in the country and before being converted into INPI by the current administration, the CDI established that the Indigenous population was all those inhabitants that were part of an Indigenous household in which the head of the house, its partner or any ascendant (mother, father, stepmother, stepfather, grandmother, grandfather, mother- or father-inlaw) have declared to speak an Indigenous language (Rubio, 2014; CDI, 2014).

According to the Special Program for Indigenous People 2014-2018 of the $\mathrm{CDI}^{8}{ }^{8}$ there were 15.7 million Indigenous inhabitants in Mexico, of which 6.6 million spoke an Indigenous language and 11.1 million were living within an Indigenous household. It acknowledged 68 different ethnic groups corresponding to 68 languages spoken across the country and it identified 25 Indigenous regions in 20 states and established that 624 of the 2,456 municipalities in the country were Indigenous (CDI, 2014).

The current administration (2018-2024), through the INPI, has presented the 2018-2024 National Program for Indigenous People, in which it establishes that in Mexico there are 68 Indigenous pueblos (ethnic groups) and the afro-Mexican people; 7.4 million of Indigenous language speakers (6.5\% of the population); 12 million people inhabiting within Indigenous households $(10.6 \%$ of the population); 25.7 million people self-perceived as Indigenous ( $21.5 \%$ of the population) and 64,172 localities with Indigenous population across the country's territory (INPI, 2018).

\section{Current state of Indigenous communities in Mexico}

According to the National Evaluation Council (CONEVAL), ${ }^{9}$ the Indigenous population in Mexico has presented an accentuated situation of poverty and vulnerability historically. In 2018, the percentage of the Indigenous population living under poverty conditions was $69.5 \%$ whereas the percentage of non-Indigenous population under similar conditions was $39 \%$. Also, the highest percentage of Indigenous population under poverty conditions are located in those localities with the lowest number of inhabitants; so, $78.7 \%$ of the Indigenous population living in poverty live in localities of under 2,500 inhabitants (CONEVAL, 2019). This means that Indigenous communities are established mainly in rural areas throughout the country that present severe conditions of marginalization and vulnerability to their inhabitants. The country's most marginalized municipalities happen to be mainly municipalities considered to be Indigenous or part of an Indigenous region located in rural areas (Figure 9.2). 


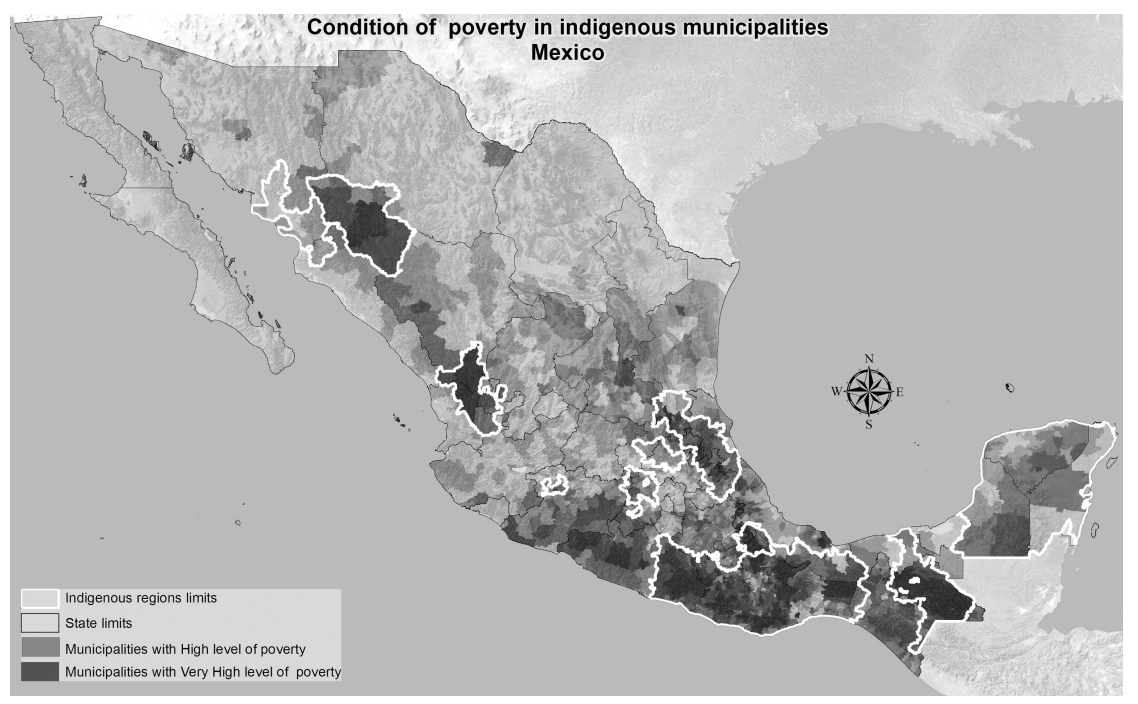

Figure 9.2 Map of Mexico Indigenous regions and marginality.

The Poverty in the Indigenous population in Mexico 2008-2018 report (CONEVAL, 2019) noted that $50 \%$ of the Indigenous population live in rural localities whilst the rest of the population is mainly integrated by migrants and their families who migrate and get established in medium-sized and big cities because they are looking for better income opportunities. Some thrive and become part of the Indigenous population that are less poor and vulnerable, representing only $6.9 \%$ of the total Indigenous population. Nearly one in four Indigenous individuals live under extreme poverty conditions in comparison with one in 20 for non-Indigenous population.

Regarding deprivation of social services (Figure 9.3), lack of access to social security has the highest incidence among the Indigenous population, followed by the lack of access to basic housing services (running water, sewage and electric power), which once again is more extreme for Indigenous populations in rural areas where only one in five persons have access to basic housing services (CONEVAL, 2019). In general, according to this report, the Indigenous population has a higher percentage of its population in five of the six social deprivation categories in comparison with the non-Indigenous population, with only a lower figure in the access to health services. This is also noticeable when comparing figures corresponding to the years 2008 and 2018 for the Indigenous population (Figure 9.3) and is the only service in which the improvement is noticeable (health). This could be due to the health program developed by the last administration called the seguro popular (popular insurance) which had almost universal coverage in terms of the population registered. Nevertheless, being registered did not necessarily mean that, in the event of any medical condition or emergency, 


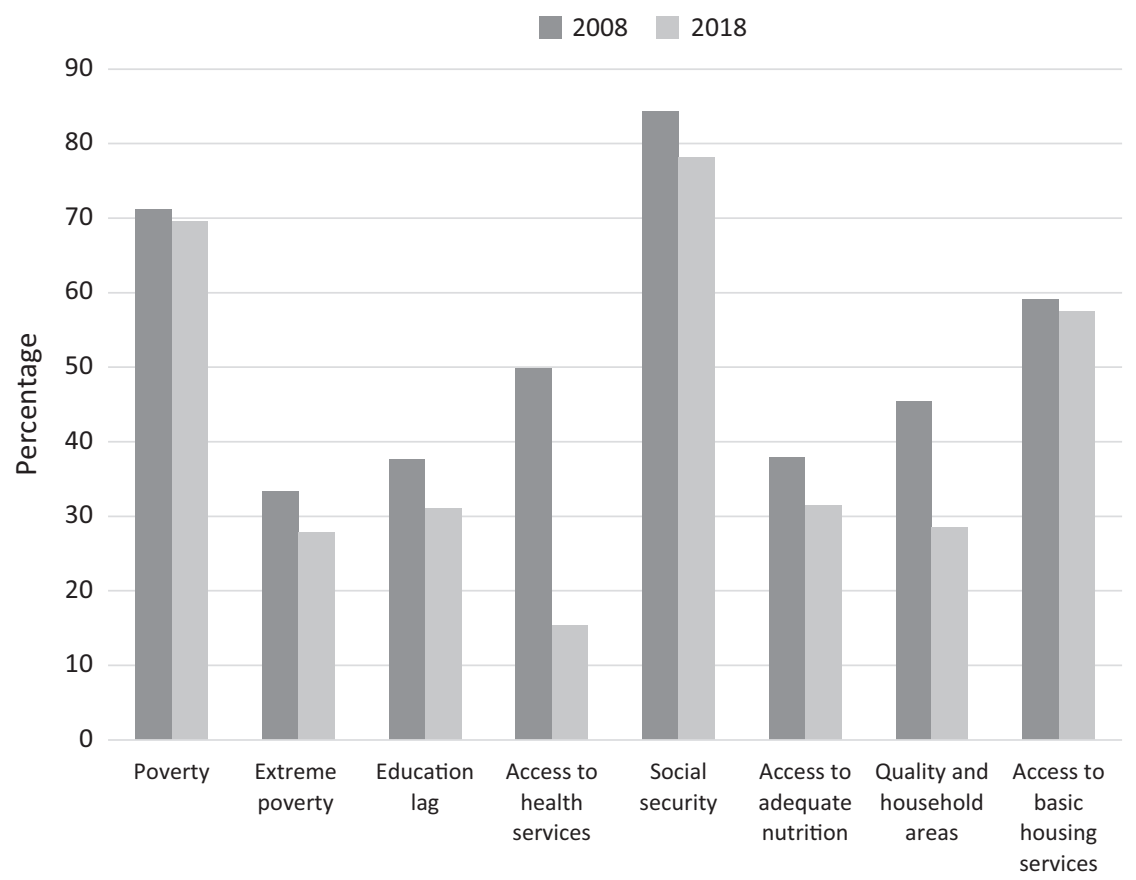

Figure 9.3 Social deprivation indicators 2008-2018 (CONEVAL).

facilities, treatment and medicines would be available in Indigenous contexts. An in-depth evaluation of the matter could help better document this subject area and aid understanding of why these problems are present.

Between 2008 and 2018, the Indigenous population under poverty conditions was reduced by 1.6 percentage points whilst during the same period for non-Indigenous population the reduction represented 2.2 percentage points. The Indigenous population members with reduced poverty conditions were mainly established in non-rural settlements. Finally, the report emphasized that poverty incidence has not been properly attended in terms of public policy for the Indigenous population since eight of every ten Indigenous Peoples members under 18 live under poverty conditions (CONEVAL, 2019).

The latest report of the United Nations (UN) special commissioner for Indigenous communities in Mexico establishes the following as the main areas of concern for Indigenous Peoples' rights: (a) land territories and natural resources; (b) development priorities, megaprojects, consultation and consent; (c) free determination and political participation; (d) violence, impunity and access to justice and (e) economic, cultural and social rights. The main recommendations presented in the report include, among others: (a) specialized attention for the recognition and protection of Indigenous communities' lands 
and territories; (b) any consultation about activities and measures that could affect Indigenous communities should be first done with Indigenous communities' members and adequate information about social, environmental and cultural impact should be provided, and no project should proceed without their free, prior and informed consent; (c) Indigenous self-government and autonomy systems should be promoted and strengthened; (d) collective and culturally appropriate protection measures in the defense of the rights of Indigenous communities and individuals at risk should be developed and the recognition of Indigenous justice systems should be reinforced; (e) efforts should be doubled to obtain specific information regarding health, education and other services and these services should be developed in consultation, coordination and collaboration with Indigenous communities in order to incorporate their proposals (Naciones Unidas, 2018).

A previous UN report carried out in 2003 established the following as priority affairs in relation to the human rights of Indigenous population in Mexico: (a) agrarian conflicts (land and resources); (b) political conflicts; (c) Indigenous communities in the justice system; (d) conflict in Chiapas; (e) the rights of Indigenous women, children and migrants; (f) education, language and culture and (g) constitutional reform and composition of Indigenous groups. The main findings pointed out in this report were (a) regardless of the efforts done by the Mexican state, the Indigenous population remain in a disadvantaged situation in relation to the rest of the population, being victims of discrimination and social exclusion; (b) there is a high and persistent level of conflicts around Indigenous communities commonly involving violence regarding agrarian, environmental and political issues; (c) the Indigenous population is vulnerable and victims of the judicial system from it suffer violations to their rights, physical integrity and even their lives with high degrees of impunity and corruption in the judicial system; (d) discrimination is manifest also in the distribution of wealth, goods and public services, the main victims within the Indigenous population being women and children (mainly female) as well as the migrant population and (e) in general, public policies regarding Indigenous population are limited and with a low budget, clearly pointing out that the Indigenous population is not a high priority for the Mexican state (Naciones Unidas, 2003).

It is evident that the problems remained the same during the 2003-2018 period. Public policies aimed to reduce the gap regarding the improvement of living conditions (health, education, economic security and housing services) as well as provide proper access to justice and conflict resolution (about land tenure, natural resources exploitation and all kind of projects) but they were neither appropriate nor relevant or sufficient judging merely by the fact that both commissioners point out the same issues as priorities to be attended to.

\section{Indigenous Data Sovereignty in Mexico: toward an agenda}

Clearly Indigenous communities in Mexico have been systematically excluded from development processes throughout the history of the country. Ever since 
the colonial period, Indigenous communities have been enslaved, marginalized and exploited through several mechanisms that ensured deprivation from their lands and resources including the violation of several of their human rights. There is not much available evidence in terms of evaluations about Indigenous-related public policy; except for some specific and monitoring reports from the National Evaluation Council mainly from Indigenous Rights and Infrastructure Programs, there are no impact evaluations with particular recommendations in order to improve general public policy for Indigenous communities.

The actual administration has established the following as priorities in the National Program for Indigenous People 2018-2024: (1) define and implement sustainable and intercultural integral development processes; (2) develop sustainable economic capacities; (3) development of social, communication, connectivity and broadcasting infrastructure; (4) constitutional and legal recognition of Indigenous rights in accordance with international treaties and jurisprudential criteria; (5) implementation of fundamental rights of Indigenous People as well as measures for the defense of land territories, natural resources and environment; (6) strengthen and reinvigorate language, values, knowledge and other elements that constitute Indigenous cultural and bio-cultural heritage; (7) develop affirmative actions and measures to secure the recognition, guarantee of and respect of Indigenous women's rights in their own contexts; (8) guarantee protection of and respect for Indigenous Peoples in a situation of vulnerability and victims of violence and discrimination rights and (9) right of participation, representation, consultation with and free prior and informed consent (INPI, 2018).

The previous Special Program for Indigenous Peoples (2014-2018) established the following priorities: (1) promote the recognition, rights and access to justice; (2) increase access to food, health and education; (3) provide services for infrastructure and housing with a sustainability approach; (4) improve the monetary and non-monetary income through the establishment of productive projects; (5) strengthen participative planning and government program coordination and (6) preserve and strengthen Indigenous Peoples culture recognizing its national heritage character. As can be observed, both programs establish access to rights, justice, participation, services and productive infrastructure as part of their priorities.

In all of these historic unsolved priorities and established proposals within the current development program, there is a common element: the use of data to generate information and knowledge and the particular way in which this information and knowledge is being integrated, used, controlled and exploited in a variety of contexts, industries, activities, processes and various stakeholders. In this sense, Indigenous Data Sovereignty (IDS) appears to be not only relevant but necessary toward creating fairer governance of Indigenous Peoples and their future prosperity.

Some of the main topics related to IDS that clearly present challenges and opportunities for Indigenous communities in the country are described in what follows (and displayed in Figure 9.4). 


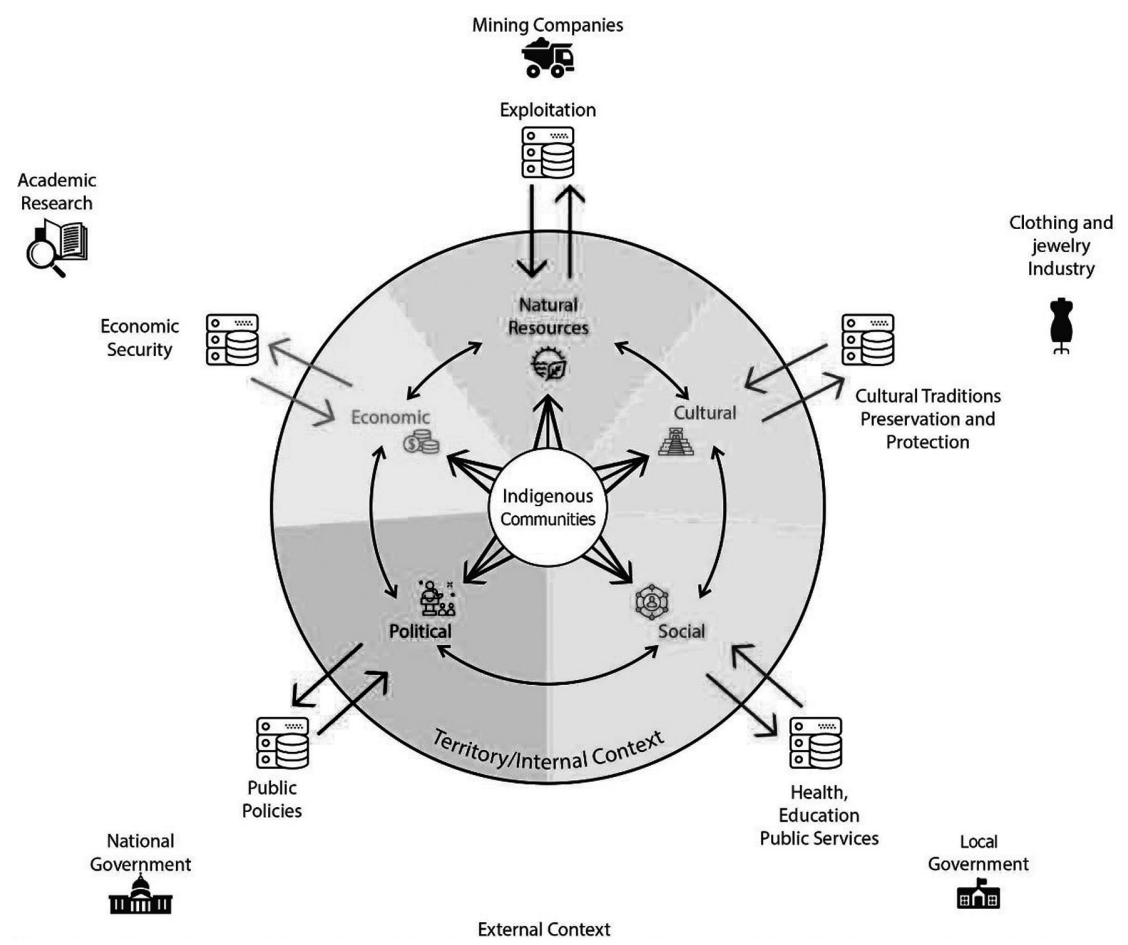

Figure 9.4 Indigenous data production and use.

\section{Natural resources}

Due to historic, economic, social and political reasons and being pursued or displaced, Indigenous Peoples have been scattered all over the country's territory into isolated regions with difficult access including a wide variety of ecosystems (e.g., desert, jungle, forest). Indigenous communities are landowners under a particular land tenure scheme in Mexico called communal lands with legal basis on the Agrarian Law, which establishes that "the community will determine the use of their lands, their division in different portions with diverse ends for the use of its goods" (Ley Agraria, 2019, p. 19). In general, Indigenous territories are related to a diverse variety of natural resources which include water, plants, wildlife, timber and minerals, to mention only some of the most relevant ones.

The exploitation and use of all of these resources correspond by law to Indigenous communities, with the exception of those regarded as strategic for national interest and well-being, which could be subject of expropriation by the state. In general, there is a lack of understanding around commercial value of most of these resources and the implication of the exploitation of them in terms of investments, infrastructure, health and environmental consequences. It has not 
been uncommon for historically external actors, such as academia, government officials and private stakeholders to conduct research to better understand and characterize natural resources within Indigenous territories sometimes without informing locals or even asking for permission.

One of the most controversial issues has been the development of extractive activities such as mining which have had a profound impact on Indigenous communities; concessions to explore and exploit mineral resources have accelerated in the past years supported by a number of legal reforms carried out in particular by the past two administrations (2006-2012 and 2012-2018 by Presidents Calderon and Peña, respectively). In this sense, it has been documented that:

between 2000 and 2012, from the 28 million hectares identified as the hard core of Indigenous territories, around 2,173,141 hectares have been given under concession, mainly for metallic mining. This means that in the last 12 years Indigenous people have lost the jurisdiction of $7 \%$ of their territory only by mining concessions and frequently communities are not even informed.

(Valladares, 2018, p. 3)

This is a clear example of how the lack of IDS has led to communities not being informed properly about their resources and the way they could be exploited with the environmental consequences of the exploitation techniques and methods including the use of heavy machinery and massive lixiviation processes mainly with sodium cyanide which is forbidden in several European countries (Boege, 2013).

Eckart Boege (2013) developed an analysis of Indigenous territories dispossession in Mexico and presents in his conclusions the following remarks: (1) some mining concessions include almost the totality of some small Indigenous communities such as Kiliwas, Kikapoo, Cucapas, Pimas, Guarijios and Nahuas; (2) the Indigenous communities most affected in terms of extension of the concessions are the Rarámuris, Zapotecos, Chatinos, Mixtecos, Coras and Tepehuanes; (3) mining companies buy or rent the land where they establish an exploitation, in case the local community refuses to sell or rent the state, supported by the mining law that allows them the right to expropriate the land in the benefit of public interest; (4) mining concessions for gold exploitation are dominant, this being the type of exploitation that uses cyanide in highly risky procedures for both human beings and the environment.

\section{Cultural heritage}

Several Indigenous cultural elements have also been subject to exploitation over the years. One of the most known cases involves the use of Indigenous patterns and techniques for clothing design purposes. In June 2019, the Mexican minister of culture accused Carolina Herrera ${ }^{10}$ of using for their own benefit embroidery techniques and identity patterns from Indigenous communities for her 2020 collection. According to the minister of culture, some of the embroidery 
used by Carolina Herrera was taken from the Otomí community of Tenengo de Doria in the state of Hidalgo and others are typical of those from Tehuantepec, Oaxaca (Friedman, 2019). There is an evident resemblance and the designer even declared that the intention of using these patterns for her collection was as homage to Mexico; nevertheless, the fact remains that Indigenous communities are not informed about the use of their patterns and never receive any kind of royalties for the use of them.

It is important to point out that among the limitations that Indigenous communities face, there is a lack of general knowledge about legal considerations related to their cultural heritage, such as the registration of patents and intellectual property protection in order to obtain the rights to them, thus avoiding or being better equipped for litigating against plagiarisms such as this fashion industry example.

\section{Social, economic and political needs and rights}

The marginalization and exclusion that Indigenous communities have suffered put them in a very fragile position since the lack of opportunities is evident and the gap with the rest of the population in the country is considerable. As already presented, the social and economic conditions under which most Indigenous Peoples live limit the opportunities for them to develop and thrive.

The most evident areas reflected in some of the public policies implemented over the years are the social and economic topics. The need for basic services improvement is imperative and the creation of economic opportunities for Indigenous Peoples has been present in most of the efforts done by the Mexican government toward development.

Regarding rights, the former CDI in 2016 presented the amplified diagnosis for the Indigenous rights program in which it remarked that:

the situation of the Mexican Indigenous population regarding the exercise of their collective and individual rights, is far from being fully reflected in national statistics and diagnosis, which makes it almost impossible to identify this population sector in front of the justice and quantitatively value the characteristics of the phenomenon. Nevertheless, important efforts to dimension the problem have been done, based on which elements have been found such as the lack of knowledge of their rights, limited capacities to enforce them, discrimination and insufficient economic resources to hire appropriate advice services and legal defense.

(CDI, 2016, p. 8)

One of the most evident limitations for Indigenous Peoples when facing legal matters is the lack of financial resources to pay for lawyers. Even though the law requires the state to provide a lawyer free of charge, these professionals have work overloads and are not prepared to work with Indigenous Peoples in terms of understanding the language and culture of those to be defended. 
Another situation relevant to Indigenous Peoples' rights is the presence of social conflicts which on occasions escalate into violent episodes. These conflicts are mainly over land property claims and because of the disrespect of political and religious diversity. Some of these conflicts result in those involved being forced to abandon their usual residency and become displaced peoples. Recently, some of these displacements have been forced due to the presence of drug cartels and the production of illegal plants such as poppy and marihuana.

Within Indigenous communities, women are among the most vulnerable. Domestic violence is not uncommon and adding to other variety of violence forms (economic, labor, psychological, etc.), these have become prioritized demands for Indigenous women along with sexual and reproductive rights. In some Indigenous communities, women are not allowed to participate in decision-making processes relevant for the entire community. Regarding access to rights, some government initiatives have been developed over the years including the project for Indigenous prisoner defense in the 1980 s and the project seeking attention to the displacement of Indigenous Peoples in the 2000s.

The CDI, in 2016, established the limited capacity of Indigenous Peoples to exercise their rights as the main problematic situation regarding the rights of Indigenous Peoples. Rights are limited by discrimination specifically with respect to culture, the lack of support for rights promotion and cultural initiatives, lack of knowledge of rights, limited access to legal support, institutional weaknesses that cause the failure to guarantee the exercise of Indigenous rights and institutional designs oblivious to the needs of cultural diversity. The recommended actions in order to strengthen Indigenous capacities included improve access to justice, protection of cultural heritage and gender equity; also, the recommended actions for the exercise of Indigenous population rights included appropriate attention to legal matters, attention to displaced Indigenous population and access to specialized health services for Indigenous communities (CDI, 2016).

Once again there are no impact evaluations available to establish the effectiveness of the proposed actions regarding Indigenous rights during the past administration, but the fact that problems remain and are fully acknowledged by the current administration in its program can give us an idea of the persistence and complexity of them. IDS could help fill the gap regarding the lack of evaluations as an appropriate approach in the design and implementation of monitoring, evaluation and learning (MEL) local systems, controlled and used by Indigenous communities.

The OECD recommends four main areas to strengthen Indigenous economies:

1. improving Indigenous statistics and data governance

2. creating an enabling environment for Indigenous entrepreneurship and small business development at regional and local levels

3. improving the Indigenous land tenure system to facilitate opportunities for economic development

4. adapting policies and governance to implement a place-based approach to economic development that improves policy coherence and empowers Indigenous communities (OECD, 2019, p. 5) 
The first of these points is basic in order to enable the successful development of the following ones, and it completely relies on IDS. The same report emphasizes that "the inclusion of Indigenous peoples in data governance will enable better data that incorporates their values and perspectives" (OECD, 2019, p. 9). The strategies suggested by this report include the inclusion of Indigenous representatives in national statistics agencies, adapting data collection to the needs of Indigenous Peoples, and providing tools for Indigenous communities to collect their own data (OECD, 2019). Nevertheless, these strategies will prove successful only to the extent that the necessary capabilities are developed among Indigenous actors, supported by appropriate technology and infrastructure availability.

\section{Conclusion}

Indigenous communities in Mexico need to be able to access, use, control and in general govern their data and information. In order to achieve data governance, public policy must be developed to remediate the three main data challenges for Indigenous Peoples: data collection, access and relevance. The first and the last are strongly related to the need to develop capacities within Indigenous communities to design and apply data collection methods and tools and also to develop skills to understand, interpret, analyze and even theorize from this data. As has been recognized internationally, Indigenous Peoples always were data stewards, collectors, analyzers and users (Kukutai and Taylor, 2016; Smith, 2016). Revitalizing these ways of knowing that have been suppressed by colonization as well as building new skills for data science and use are critical. However, the main challenge remains the condition of educational lethargy present among Indigenous children and youngsters (Figure 9.3) in addition to the necessity of better conditions for them to complete not only basic education but also to pursue higher degrees. There remains a critical need for IDS-related topics in the curricula of middle grades to create awareness among youth and to promote participation and consciousness regarding these issues.

The main limitation for accessing data is the general lack of infrastructure and technology in Indigenous communities. In general, Indigenous communities have limited access to modern technologies such as personal computers with an Internet connection. The federal government, foundations and WHO must facilitate access to technology for Indigenous communities in order to enhance access to data and improve decision-making processes on several levels including personal but also community and municipal. At a municipal ${ }^{11}$ level, increased access to and relevance of data would enrich the participatory construction of municipal development plans required by law from each local administration thereby creating a scenario of better data for governance.

Finally, regarding IDS discussion in general from a global perspective, Latin American countries, particularly Mexico in this case, are only recently presenting the topic as part of the academic, public policy and general public discussion, unlike the CANZUS countries in which IDS has already obtained a certain 
level of dissemination reflected in the fact that IDS national networks have been established (for instance, the USIDSN and the Aotearoa Māori Data Sovereignty Network among others). A lot remains to be done and many challenges remain since a national agenda around IDS is only in the early stages of construction. This chapter presents the most evident of these challenges and there is still a long way toward achieving Indigenous emancipation.

\section{Notes}

1 Huarache is a popular style of handmade pre-Columbian footwear similar to a sandal.

2 Tortilla is a typical Mesoamerican thin flatbread made from corn.

3 Petate is a bedroll typical from Mesoamerica woven from fibers of palm.

4 The term mestizo was used by the Spanish Empire during the 16th century to refer to one of the castes that integrated the social stratification based on race hierarchies imposed in the American colonies which was the mix of White (European) and Indigenous (Amerindian) races.

5 www.inegi.org.mx.

6 https://www.inegi.org.mx/programas/enadid/2018/default.html.

7 The change from CDI to INPI responded primarily to political needs, since the Lopez administration has insisted in promoting a transformation in the country's public administration; thus the creation of new "Institutes". Nevertheless, the laws that create both CDI and INPI are quite similar, maintaining the general purpose of the agency.

8 This program used data obtained from the 2010 census.

9 CONEVAL uses data primarily from the censuses.

10 Carolina Herrera is a fashion designer founder of the Carolina Herrera fashion firm (www.carolinaherrera.com).

11 Municipalities are the basic political and administrative units in Mexico; the country as a federal republic is integrated by states and these states are divided into municipalities, which have their own local governments. Municipalities with more than $40 \%$ of their population regarded as Indigenous are also regarded as Indigenous municipalities.

\section{References}

Boege, E. (2013). El despojo de los indígenas de sus territorios en el siglo XXI. Movimiento Mesoamericano Contra el Modelo Extractivo Minero. Retrieved from https://movimie ntom4.org/2013/06/el-despojo-de-los-indigenas-de-sus-territorios-en-el-siglo-xxi/.

Carrasco, V.T. and Alcázar, C.T. (2009). Los Pueblos Indigenas y los Censos en México y América Latina: la Cultura en la Definición de su Identidad. Retrieved from https://ar chivos.juridicas.unam.mx/www/bjv/libros/6/2638/18.pdf.

CDI (Comisión Nacional para el Desarrollo de los Pueblos Indígenas). (2014). Programa Especial de los Pueblos Indigenas 2014-2018. Retrieved from https://www.gob.mx/ $\mathrm{cms} /$ uploads/attachment/file/32305/cdi-programa-especial-pueblos-indigenas-2014-20 18.pdf.

CDI (Comisión Nacional para el Desarrollo de los Pueblos Indígenas). (2016). Diagnóstico Ampliado. Programa de Derechos Indigenas. Dirección de Derechos Indígenas 2016. Retrieved from http://www.cdi.gob.mx/coneval/2015/cdi_prodei_diagnostico_ampliad o_2016.pdf.

CONAPO (Consejo Nacional de Población). (2005). Proyecciones de Indigenas de México y las Entidades Federativas 2000-2010. Retrieved from http://www.conapo.gob.mx/ work/models/CONAPO/indigenas_2010/Proyindigenas.pdf. 
CONAPO (Consejo Nacional de Población). (2020). Instituciones CONAPO. https://datos .gob.mx/busca/organization/about/conapo.

CONEVAL (Consejo Nacional de Evaluación de la Política de Desarrollo Social). (2019). La Pobreza en la Población Indigena de México 2008-2018, August, 2019. Retrieved from https://www.coneval.org.mx/Medicion/MP/Documents/Pobreza_Poblacion_ind igena_2008-2018.pdf.

Constitución Politica de los Estados Unidos Mexicanos. (August 9, 2019). Retrieved from http://www.diputados.gob.mx/LeyesBiblio/pdf/1_090819.pdf.

ENADID (Encuesta Nacional de la Dinámica Demográfica). (2018). Retrieved from https ://www.inegi.org.mx/programas/enadid/2018/default.html\#Tabulados.

Friedman, V. (June 13, 2019). Carolina Herrera: ¿apropiación cultural u homenaje? The New York Times. Retrieved from https://www.nytimes.com/es/2019/06/13/espanol/cult ura/carolina-herrera-disenos-mexicanos.html.

Indigenous and Tribal People Convention, 1989 (No. 169). (1989). Retrieved from https ://www.ilo.org/dyn/normlex/en/f?p=NORMLEXPUB:12100:0::NO::P12100_ILO_ CODE:C169.

Indigenous Peoples. (September 24, 2019). Retrieved from https://www.worldbank.org/en /topic/Indigenouspeoples.

INEGI. (2010). Censo de Población y Vivienda 2010. https://www.inegi.org.mx/progr amas/ccpv/2010/.

INEGI (Instituto Nacional de Estadística, Geografía e Informática). (2020). Censos y Conteos de Población y Vivienda. Serie Histórica Censal e Intercensal. https://www .inegi.org.mx/programas/ccpv/2020/default.html.

INPI (Instituto Nacional de los Pueblos Indígenas). (2018). Programa Nacional de los Pueblos Indigenas 2018-2024. Retrieved from https:/www.gob.mx/cms/uploads/atta chment/file/423227/Programa-Nacional-de-los-Pueblos-Indigenas-2018-2024.pdf.

INPI. (2020). INPI ¿Qué hacemos?. https://www.gob.mx/inpi/que-hacemos.

Knight, A. (2004). Racismo, Revolución e Indigenismo: México 1910-1940. Volumen 1: Cuadernos de Estudios Sobre el Racismo. México: Universidad Autónoma de Puebla.

Kukutai, T. and Taylor, J. (2016). Data sovereignty for indigenous peoples: current practice and future needs. In T. Kukutai and J. Taylor (eds.), Indigenous Data Sovereignty: Towards an Agenda, 1-24. CAEPR Research Monograph, 2016/34. Canberra: ANU Press.

Ley Agraria. (November 10, 2019). Retrieved from http://www.diputados.gob.mx/Le yesBiblio/pdf/13_250618.pdf.

Naciones Unidas. Asamblea General. (Junio 28, 2018). Informe de la Relatora Especial de los Derechos de los Pueblos Indígenas Sobre su Visita a México. Retrieved from https:/ /www.hchr.org.mx/images/doc_pub/2018-mexico-a-hrc-39-17-add2-sp.pdf.

Naciones Unidas. Asamblea General. (Diciembre 23, 2003). Informe del Relator Especial Sobre la Situación de los Derechos Humanos y las Libertades Fundamentales de los Indigenas, Sr. Rodolfo Stavenhagen. Retrieved from http://www.hchr.org.mx/images/ doc_pub/informerelatormexico.pdf.

OECD. (2019). Linking Indigenous Communities with Regional Development, OECD Rural Policy Reviews. Paris: OECD Publishing. doi:10.1787/3203c082-en.

Pla Brugat, D. (2011). Mas desindianización que mestizaje. Una relectura de los censos generales de población. Dimensión Antropológica, 18, 69-92. Retrieved from https:// www.dimensionantropologica.inah.gob.mx/?p=7401.

Romero Flores, J. (1978). Historia del Congreso Constituyente 1917-1917. México: Editorial Gupy S.A. Retrieved from http://biblioteca.diputados.gob.mx/janium/bv/dp/ hist_cong_const.pdf. 
Rubio Badán, J.C. (2014). Censos y Población Indígena en México. Algunas Reflexiones. Serie Estudios y Perspectivas. México: CEPAL. ISSN:1680-8800. Retrieved from https://repositorio.cepal.org/bitstream/handle/11362/36858/S1420252_es.pdf?seque nce $=1 \&$ isAllowed $=y$.

Smith, D.E. (2016). Governing data and data for governance: the everyday practice of indigenous sovereignty. In T. Kukutai and J. Taylor (eds.), Indigenous Data Sovereignty: Towards an Agenda, 117-138. CAEPR Research Monograph, 2016/34. Canberra: ANU Press.

United Nations. (September 13, 2007). United Nations Declarations of the Rights of Indigenous Peoples. Retrieved from https://www.un.org/development/desa/Indigenou speoples/wp-content/uploads/sites/19/2018/11/UNDRIP_E_web.pdf.

Valladares, de la C.L.R. (2018). El asedio a las autonomías indígenas por el modelo minero extractive en México. Iztapalapa. Revista de Ciencias Sociales y Humanidades, 85(39), 103-131, julio-diciembre de 2018. ISSN:2007-9176. Retrieved from http://www.scielo .org.mx/pdf/izta/v39n85/2007-9176-izta-39-85-103.pdf. 